\title{
Dark tourism in Romania: from concept to reality
}

\author{
L. Ghetau \& L. V. Esanu \\ Faculty of Geography and Geology, Iasi University, Romania
}

\begin{abstract}
Romania's current touristic image is struggling to maintain itself above a floating point. This situation is due to the fact that the country's brand has been very poorly designed, not being able to underline the true value of its cultural heritage, thus making it hardly distinguishable among other destinations.

To do just this, we have decided that the best way is to first come up with a set of proper regional brands and from there on work our way up to creating a national brand that would be based on a solid regional structure.

We think that Transylvania is the perfect place to start Romania's rebranding process, firstly because it lies closest to the western part of Europe making it more accessible; and secondly because it already is very popular among foreign tourists and by probing deeper into the market we shall be able to maximize its touristic potential.

Our plan is to implement a new form of tourism, for Romania, which has proven to be very popular in Western Europe and should guarantee a great success for Transylvania too. The type of tourism that we are referring to is dark tourism.

Transylvania contains a great deal of historical sites that are renowned for the gruesome punishments or bloody executions that have take place in the country's past, thus making it an excellent candidate for this type of tourism.

Dark tourism represents the perfect choice for creating a solid, mature touristic brand because it is able to correctly promote and conserve the country's true historical origins by laying on the table concrete places and facts regarding our past, while at the same time being able to keep up with current trends that are evolving in the global scene of tourism.

So, through dark tourism Transylvania shall become a more attractive touristic destination.
\end{abstract}


Keywords: dark tourism, Transylvania, re-branding, cultural identity, sustainability, implementation.

\section{Introduction}

Up until now Romanian tourism has relied mainly on natural resources to draw in tourist flows, but in order to keep up with the ever growing changes and demands that are taking place in the global tourism industry we have to probe deeper, to come up with new and up to date methods for promoting national sights.

Government officials responsible for this part of the economy have done their best to some degree by focusing more on cultural aspects. Unfortunately, not all efforts have summed up to generate positive outcomes. For example, a few modest attempts of creating a national brand have been noticed but in every case the end result has been less than satisfactory; all brands not being able to identify a clear unique selling point capable of setting Romania apart from other destinations like Turkey, Poland or Azerbaijan which rely on similar approaches.

These unpleasant turnouts mentioned earlier are due to the fact that in the branding process specialists have just pieced together different images, traditions, aspects of Romanian lifestyle rather than focusing their attention on creating a series of smaller, more accurate regional brands which could later be merged to form a truly unique national image.

This brings us to the purpose of our current paper, which is to try and come up with a solid regional brand capable of taking us one step forward to uncovering the unique selling point mentioned earlier.

In order to do just this we have chosen Transylvania as a starting point because it already benefits from a lot of free publicity mainly due to Hollywood movies, which regrettably has lead foreign tourists to expect an entirely different place form the one in reality. To correct this false impression and at the same time try to still make it an interesting place to visit we have decided to combine its many historical aspects with a new form of tourism for Romania, namely dark tourism. This would represent a new approach toward promoting national sights even though in Western European countries, like the United Kingdom or France, it has been known by this name and practiced as a form of tourism since the early 1990's.

Even though our country has its share of black spots, as they are referred to by specialists, for some reason this type of tourism has not caught the attention of any Romanian researchers, making this paper one of the first and only official attempts in formulating a plan that will actually put Romania on the map as a destination for dark tourism enthusiasts.

In order to further detail our finding and turn it into concrete facts we have broken up the discussion into separate chapters which will tackle the idea of taking dark tourism in Transylvania from a theoretical proposition to reality.

Keeping track of people's increasing interest for alternate ways of spending their free time, dark tourism would account for a very promising and successful 
start in the rebranding process of Romania because it focuses on combining historical fact with modern, up to date marketing strategies.

So, as mentioned in the above paragraphs the following chapters shall fully describe as to how dark tourism will become the main element in redefining Transylvania's image and help conserve not only its true historical past but also the built environment that relates to these events.

\section{Dark tourism}

As a form of travel Dark Tourism may seem like a new addition to the touristic industry, but actually it goes back all the way to the time of the Roman Empire when people would gather in the coliseum to watch as others duelled to the death. Similar activities have been recorded throughout history. The most well known period for acts of cruelty against mankind has been the dark ages, when people were known to come from all surrounding villages to assist at various public events which involved physical punishment (for example: hangings, decapitation, torture, etc.), or pilgrims who travelled to tombs and sites of religious martyrdom. A similar trend was set, at the dawning of the $17^{\text {th }}$ century, by famous personalities of the literary world (for example: John Evelyn, James Boswell and Charles Dickens) which looked into different death related beliefs of many cultures [1].

So far, the historical trends mentioned above have uncovered only the tip of the iceberg when it comes down to enumerating thanatopic events, but they have all pointed out quite clearly the fact that people have always been drawn to the darker aspects of living. Even though with the passing of time they have seen a decrease in intensity, these activities have not disappeared they have just taken a new form, blending in with today's standards; dark tourism being seen as just another phase in the long living 'thanatoptic tradition' [2].

In the past years this particular form of travel has captured the attention of researchers, like Malcolm Foley, J. John Lennon, Smith V., Blom T., and Philip R. Stone, who have seen it as being a branch of cultural tourism and have not hesitated to come up with suitable names, like 'morbid tourism', 'grief tourism', all quite capable of fully describing its essence.

The term of dark tourism has been patented by two researchers, Malcolm Foley and J. John Lennon, and was created in order to better portray '...the phenomenon which encompasses the presentation and consumption (by visitors) of real and commodified death and disaster sites' [3].

In 2005 Philip Stone from the University of Central Lancashire considers that 'Dark tourism is the act of travel and visitation to sites, attractions and exhibitions which has real or recreated death, suffering or the seemingly macabre as a main theme' [4].

Looking at both definitions one cannot help but wonder if the authors have managed to capture every aspect contained by dark tourism or if the different points of view from which the subject is being observed are the best ones. Browsing through different publications regarding this subject and by piecing together information another element of dark tourism has arisen; setting it apart 
from other types of cultural tourism which usually end up resembling one another. The ability of interacting on a more advanced, more personal level with one of the oldest and probably most mysterious human feature, curiosity, which is its most important unofficial trademark. Few other types of tourism have been known to interact with human beings on such a intense level, even if we are speaking of imagination or live facts; none have managed to implicate at the same time or to such a degree both the physical and spiritual aspects of our existence.

Even though it is not such a popular choice among everyday tourists, which cannot get passed its tuff exterior, dark tourism actually has many positive influences on both the built and natural environment. Locations hosting such attractions benefit from the full attention of government and local authorities, through different conservation and development policies, which play an important role in conserving not only the actual monument but its surroundings also in order to maintain the element of authenticity. This in turn starts a chain reaction which extends its effects on the local population mobilising their interest toward building a long lasting local business and at the same time keeping alive a page of the world's history. Living proof of such sites can be found for instance in South Africa, 'the battlefields of the Zulu and Boer Wars within KwaZulu Natal have been maintained and developed as tourism sites with the support and participation of local tourism authorities and communities' [5] and another one in London, 'Westminster Abbey, where charging is not only a method of funding a historic building but also a form of visitor control, since the admission fee acts as a mechanism for limiting demand that might otherwise be overwhelming' [1].

As mentioned in the above paragraphs the academic interest in developing a suitable theoretical framework for dark tourism has played a very important role in helping to better understand and further manage the newly discovered 'black spots'. Concrete examples of such contributions brought by researchers have been proven by Rojek's work through which he brings into perspective three different examples of Black Spots - the annual pilgrimage to the site where James Dean died in 1955, the annual candlelight vigil in Elvis Presley's memory in Tennessee and JFK's assassination. Later on in a more precise taxonomy he distinguished the earlier mentioned examples as being postmodern spectacles; other attractions like cemeteries were seen as being 'nostalgic' sites and finally disaster sites were seen as being distinct from Black Spots forming a separate group [1].

Another great contribution was brought by Seaton, who remarks the long standing history of dark tourism and suggests that it is a phenomenon which has risen from various motives brought on by those who choose to visit these sites of death [1].

Even so, despite all the contributions brought on in order to better understand the true nature of this human attraction toward death and to better manage the associated landmarks, critics still argue that such sites should be left free of access for all those wishing to pay their respects, overlooking the important fact that without such management initiatives these sites would be lost through acts 
of vandalism or space consuming real-estate plans. As all other types of monuments, death sites have an equal right to be kept alive and respected because they also reflect upon the many facets of human culture. Denying the presence of death or different aspects related to it, found in everyday life, means accepting ourselves as being half alive.

Many of those who disapprove of dark tourism have overlooked another very important aspect, besides those related to death, namely the effect that time and Mother Nature have had upon these monuments, complementing the initial manmade features and finally turning them into unique artistic landscapes [1].

Dark tourism must be seen for its interdisciplinary character and respected for its deep rooted nature in history and in human perception of death's existence. As a type of tourism it is very important to understand that its destinations are not intended to be overly accessible, thus making for an excellent promoter of sustainability and conservation.

\section{Case study: Transylvania}

After crossing over from a communist leadership, bent on fully industrializing the national economy, toward a democratic one, in 1989, Romania has been trying to peace itself together and pick up from where it left off in the interwar period, when economically and culturally speaking it was an example of prosperity; and like any other activity, tourism made no exception, it too being affected by the country's unstable economic situation.

To have a better understanding of how Romanian tourism has gotten where it is today, a quick description of certain decisions that have been made by government officials over time is in order.

The Romanian communist period represents the starting point, when government officials disregarded tourism and other leisure related activities as being important national income sources, thus leaving an entire economical sector unmanaged. Back then tourism was mainly associated with trips to the seaside or picnics in the low mountain regions, coming nowhere near to today's image. Basically, almost everything relied on natural resources, cultural aspects being set aside, with little to no concern for management or conservation.

Shortly after the 1989 revolution, followed a ten year transition period in which the national economy plummeted, in which tourism was very badly affected. There were some poor attempts of designing a national brand, with slogans like 'come as a tourist, leave as a friend', in order to revive the country's image, but to no real success.

By the years 2004 and 2007, when Romania became a member of the European Union, the touristic sector had began to compete with neighbouring countries like Bulgaria or Poland, which from a touristic point of view shared a similar level of development. Some progress could be seen but the manner in which it was obtained resembled that of the early post communist period. Today, government officials are still experimenting with different strategies in order to improve the country's image. Currently they are working on another national brand, but for such a process to be successful, changing the champagne slogan 
from time to time or testing the public with different cultural aspects, which are gathered and put into presentations, to see which shall draw more attention is not the proper way of doing it; creating a national brand is not a trial and error process, it is a bottom up procedure (starting off at a regional level and working up toward a national one) relying on detailed studies of touristic flows, motives that drive them to visit a certain place, etc.

Basically, creating a brand is a compromise between promoting what the country has to offer and what visitors are interested in experiencing most. Therefore reaching the heart of the discussion, where dark tourism is seen as the prime candidate responsible for creating the first regional brand for Romania; hopefully leading to similar future actions for the remaining regions in order to narrow down the search and uncover what is truly representative for the country, in order to obtain the solid national image that is currently sought after by the Romanian government.

Choosing Transylvania, and not any other place in Romania to become the country's first dark tourism destination, can be confirmed by many arguments which include recent past moments when it was inaccurately portrayed by movie producers as being a Goth cliché, this amateur description being nowhere near the true historical and cultural significance, automatically reflecting a distorted image upon the rest of Romania.

Implementing dark tourism in the Transylvania region would represent the perfect strategy in reviving its tarnished image and further help create a solid starting point in uncovering Romania's true cultural values, this being done by trying to benefit from the existing publicity and combining it with dark tourism's reputation for creating mature but also captivating destinations.

Before shedding light upon the tools and methods that shall be used to implement this new addition to the Romanian 'touristic landscape', a brief presentation of different sites is necessary in order to display the region's potential.

Following a chronological order, first up would be the castle belonging to the Corvinus family which dates back to the year 1443, remarkable for its architecture which incorporates different construction styles (both military and civil) and for the many bloody legends surrounding it [6]. One of these legends involves the well which can be found even today inside castle grounds. Legend says that after a battle three Turkish soldiers were taken prisoners inside the castle. They made a deal with the owner of that time, in which he promised to set them free if they would dig. After fifteen years of work they found water but they were never set free because the owner John of Hunedoara, with whom they made the deal, had died and his wife, Elisabeth Szilagyi, decided not to respect the word of her husband. As a final act of protest before dying they carved in the stone wall "You have water but no heart" trying this way to revenge the lack of word from the family side [7]. Other legends involve brutal executions (decapitations, hangings) which took place inside the castle walls and prisoners which were tortured until death in the dungeons found below grounds. According to the classification, developed by Philip Stone, which divides sites by their origins, beginning analysis and managerial action in the thanatourism 
developments [1] the Corvinus Family Castle fits in as a site of functional change with man-made origins, thus taking the first step toward proving the possibility of implementing dark tourism.

A second choice is Fork Hill found in the city of Alba Iulia. This became a historical landmark when on the 28th of February 1785 over six thousand people were forced to watch the brutal execution of the three brave men responsible for leading a major rebellion. After the brutal murder, the lifeless bodies were chopped into pieces in order to be sent to every surrounding town and the organs were buried on sight in order to discourage any future acts of disobedience [8]. As a dark tourism site it fits the specifications found in the category entitled 'Fields of fatality', which basically represents areas known for commemorating death or fear [1].

Another location found in the Transylvania region which remained known throughout history for acts of cruelty against human beings is the prison located under the Deva Stronghold. In the 1960's the Bolshevik invaders proclaimed a law stating that all jewellery and other valuable possessions should be handed over in thirty days, failure to meet the specified term resulting in a five year sentence [9]. Those found guilty were incarcerated without trial in the prison located under the Deva Stronghold. Fourteen inmates were shoved into each cell which normally was built for no more than six and were further subjected to inhuman treatment; the small windows of the cells being boarded up in order to take away any source of fresh air and light. After short periods almost all prisoners died because of starvation or from a lack of oxygen, their bodies being left there to decompose along sides those waiting helpless to suffer the same fate [10]. The site in question relates to a section in the earlier mentioned classification called Houses of horror - buildings associated with death and horror [1].

Similar locations are the Kemeny Castle which served as a labour camp for political personalities which were condemned for disagreeing with the changes brought on by the communist regime, this former 'house of horror' presently serves as a sanatorium [11]; the Gherla Prison was also used to incarcerate political personalities which questioned the authority of the communist government, today it is still functional housing common law offenders but the old parts of the buildings have been left at the mercy of time [12]; the 'Emil Racovita' Speleological Museum which is famous for housing alongside different grab samples a dungeon which dates back to the dark ages (approximately 700 years old), used to incarcerate and torture the hard criminals of that time [13]. As dark tourism destinations they fit in the same category as the prison located under the Deva Stronghold, fully deserving the name of 'houses of horror'.

Even though it may seem like a summary description, in reality, pinpointing the future to be promoted locations represents a very important step in any process of implementation because in the absence of this simple procedure selecting the proper methods or instruments cannot commence. Once the potential destinations have been pointed out, the process of implementation is nothing more than a simple task of elaborating a series of methods capable of 
introducing and establishing a logical connexion between the type of tourism in question, dark tourism in this case, and the chosen area for implementation.

In order to actually get the process started, an interregional partnership is needed; consisting of specialists in tourism, gathered from the local councils of every major city found within the geographical boundary of the Transylvania Region. The main focus of the group would be related to all aspects concerning the implementation of dark tourism and further management tasks, like evaluating the current status of sites which shall further be promoted, checking if they meet certain public safety standards, etc.

Forming such a comity is possible by turning to government policies through which there have been created a series of development axes fully suitable for fully all types of sustainable development. For the current proposal development axes number five, called 'Sustainable development and promoting tourism', is seen as being most suitable. Within the mentioned axes there are a series subchapters created in order to address correctly any situation that may arise, in this case subchapter 5.3, called 'Promoting touristic potential and creating the necessary infrastructure for promoting Romania as a touristic destination', has been chosen because it contains a project specially designed for creating different groups, organizations responsible with developing Romanian tourism [14].

By accomplishing the previous step the baseline for further implementing dark tourism shall be established, from here on a series of other proposals for implementation can be engineered.

Building a regional brand for Transylvania based on a dark tourism background would help the region obtain a concrete external image and at the same time make visitors curious to see what it has to offer. Making it become reality involves the same development axes and subchapter, only that for this next step a different project will be used, entitled 'Encouraging and consolidating internal touristic activities by promoting diverse aspects of cultural heritage' [14]. After its creation, further activities designed to promote the new dark tourism regional brand would also be stared, mainly through an internet homepage dedicated to portraying Transylvania's new image and prior to this web site illustrated brochures shall be printed; all these measures being supported by the same policy.

Another method would be restoring the original architecture of the old buildings closest to the sites in order to magnify the effect of the site's past reputation and at the same time maintain the authentic look as much as possible; support for the current initiative can be found in the number five development axes, 'Sustainable development and promoting tourism', subchapter 5.1 - 'The restoration and management of cultural heritage' and even traditional homes could be refurbished through the FIDA development fund [14].

A final method for implementation and further successful development of dark tourism, in the Transylvania region, would be to make contact with other communities from other countries which have been successful in adopting this type of tourism and organise different events where they shall be invited to share different problems which have been overcome by them along the way. 
Financially speaking, support for the methods and polices which have been mentioned in the above paragraphs, can be covered by a series of loans which were designed by the European Union in collaboration with the Romanian Bank for Development (R.B.D.), especially for sustainable development and promoting touristic activities. Serving as a concrete example is the 'E.U. R.B.D. loan for touristic development' which was designed to encourage innovation and sustainability of touristic activities; this type of loan contains financial support both from the European Union and from the Romanian Ministry in charge of touristic development, it also offers a consultant in order to supervise and aid in any problems that may arise along the way [15].

Successfully turning Transylvania into a dark tourism destination would represent not only setting aside all the years of bad publicity by promoting real historical sites and facts but also a promising start toward a truly sustainable developing touristic sector.

\section{Summary}

The current paper, entitled 'Dark tourism in Romania from concept to reality', sets out to prove that Transylvania's external image, as one of the World's most popular Goth cliché, can be corrected with the help of a new type of tourism called dark tourism, which has proven to be very popular in other countries, like the United Kingdom, France, Ukraine, Poland and most of all in the United States of America.

Another motive for which dark tourism has been chosen was because of its non-invasive nature, managing to keep alive sites that were once threatened by an advanced state of moral neglect and physical decay, it brings out cultural aspects that were seen and maybe still are seen as being taboo or horrifying but which have none the less represented an important part of existence. In its present form, as dark tourism, or in any other shape taken throughout the course of history, it has always managed to interact and captivate countless generations, proving time and again man's fascination with all aspects related to death.

Perhaps the most prized attribute of dark tourism is its manner of taking something as commonly known as death and turning it into a successful method not only for generating income or publicity but also for promoting sustainability and unifying local communities.

Successfully establishing Transylvania as a dark tourism destination would prove that Romania knows how to overcome its various weak points and adapt to present changes.

Integrating this national emblem in the ever-growing network of sites will surely open up other future possibilities for development.

\section{References}

[1] Sharpley, R. \& Stone, P.R., (eds). The Darker Side of Travel: The theory of Dark Tourism, Bristol, United Kingdom, 2009. 
[2] Seaton, A. V., Guided by the Dark: From Thanatopsis to Thanatourism, International Journal of Heritage Studies, pp. 234 - 244, 1996.

[3] JFK and Dark Tourism: A Fascination with Assassination. International Journal of Heritage studies, pp. 198 - 211, 1996.

[4] Dark Tourism, www.dark-tourism.org.uk

[5] Moeller, M. Battelfield tourism in South Africa with special reference to Insandlwanna and Rorke's Drift KwaZulu-Natal. Unpublished MPhil thesis, Faculty of Economy and Management Sciences, University of Pretoria, 2005

[6] The history of the Corvinus family castle www.misiuneacasa.ro/goticistorie-sau----castelul-huniazilor-.html

[7] The Crovinus family Castle www.ropedia.ro/romania/obiectiveturistice/prezentare/Hunedoara/Hunedoara/Castelul_Huniazilor/

[8] Fork Hill www.albaiulia.mconet.biz/alba-iulia/222-de-ani-de-la-martiriultaranului-de-cremene-dealul-furcilor-alba-iulia 238 287699.html

[9] The Deva Stronghold www.hartadeva.ro/atractii +turistice-1-cetati-3442262-dealul+cetatii

[10] The city of Deva www.orasuldeva.ro/deva/index.php?option= com content\&task $=$ view\&id $=85 \&$ Itemid $=156$

[11] The Kemeny Castle albaiulia.mconet.biz/alba/aiud-lagar-de-exterminarepentru-opozantii-sistemului-comunist-judetul-alba_239_265454.html

[12] The Gherla Prison www.miscarea.net/dima-amintiri-gherla.htm

[13] The 'Emil Racovita' Speleological Museum http://www.citynews.ro/ cluj/din-oras-10/cele-mai-vechi-ziduri-din-clujul-medieval-zac-innecunoscut-66901/

[14] Government financing www.finantare.ro/por-2010-programul-operationalregional_ghid-2010.html

[15] E.U. - R.B.D. loan for touristic development www.finantare.ro/credit1040-Pachetul-EU-Turism-BCR.html 